Belgian hospitals, 1991 to 1995. Infect Control Hosp Epidemiol 1996:17:503-508.

17. Johnson Z, Fitzpatrick P, Hayes C, Sayers G, Pelly H, McDonnel B, et al. National survey of MRSA: Ireland, 1995. J Hosp Infect 1997;35:175-184.

18. Richet H, Wiesel M, Le Gallou F, Andre-Richet B, Espaze E. Methicillinresistant Staphylococcus aureus control in hospitals: the French experience. Association des Pays de la Loire pour l'Eviction des Infections Nosocomiales. Infect Control Hosp Epidemiol 1996;17:509-511.

19. Le Coustumier A, Gueudet P, Lecaillon E, Bland S, Hanesse B, Collège de Bactériologie V, et Hygiène des Hôpitaux de France. Incidence de Staphylococcus aureus méticilline-résistant dans 95 hôpitaux non universitaires en France. Medecine \& Maladies Infectieuses (Paris) 1996;26:634-643.

20. Cailleaux V, Talon D, Thouverez M, Bailly P, Mulin B, Michel-Briand Y. Staphylococcus aureus méticillino-résistant: importance et transmission croisée dans l'Est de la France. Medecine \& Maladies Infectieuses (Paris) 1996;26:475-481.

21. Collège de Bactériologie-Virologie-Hygiène du CHU de Paris. Surveillance des staphylocoques dorés et klebsielles multirésistantes à l'Assistance Publique-Hôpitaux de Paris (1993-1996). Bulletin Epidémiologique Hebdomadaire (Paris) 1998;41-43.

22. Garner JS, Jarvis WR, Emori TG, Horan TC, Hughes JM. CDC definitions for nosocomial infections, 1988. Am J Infect Control 1988;16:128-140.

23. Aubry-Damon $H$, Legrand $P$, Brun-Buisson $C$, Astier A, Soussy CJ, Leclercq R. Reemergence of gentamicin-susceptible strains of methicillin-resistant Staphylococcus aureus: roles of an infection control program and changes in aminoglycoside use. Clin Infect $D$ is 1997;25:647-653

24. Lemaitre N, Sougakoff W, Masmoudi A, Fievet M-H, Bismuth R, Jarlier V. Characterization of nosocomial spread of methicillin-resistant Staphylococcus aureus involved in nosocomial spread. J Clin Microbiol 1998;36:81-85.

25. Muder RR, Brennen C, Wagener MM, Vickers RM, Rihs JD, Hancock
GA, et al. Methicillin-resistant staphylococcal colonization and infection in a long-term care facility. Ann Intern Med 1991:114:107-112.

26. Kauffman CA, Bradley SF, Terpenning MS. Methicillin-resistant Staphylococcus aureus in long-term care facilities. Infect Control Hosp Epidemiol 1990;11:600-603.

27. Hoefnagels-Schuermans A, Borremans A, Peetermans WE, Van Lierde $\mathrm{S}$, Reybrouck G, Van Eldere J. Origin and transmission of methicillinresistant Staphylococcus aureus in an endemic situation: differences between geriatric and intensive-care patients. J Hosp Infect 1997;36:209. 222.

28. Strausbaugh LJ, Jacobson C, Sewell DL, Potter S, Ward TT. Methicillinresistant Staphylococcus aureus in extended-care facilities: experiences in a Veterans' Affairs nursing home and a review of the literature. Infect Control Hosp Exidemiol 1991;12:36-45.

29. Thomas JC, Bridge J, Waterman S, Vogt J, Kilman L, Hancock G. Transmission and control of methicillin-resistant Staphylococcus aureus in a skilled nursing facility. Infect Control Hosp Epidemiol 1989;10:106110.

30. Coello R, Jiménez J, Garcia M, Arroyo P, Minguez D, Fernandez C, et al. Prospective study of infection, colonization and carriage of methicillinresistant Staphylococcus aureus in an outbreak affecting 990 patients. Eur J Clin Microbiol Infect Dis 1994;13:74-81.

31. Girou E, Pujade G, Legrand P, Cizeau F, Brun-Buisson C. Selective screening of carriers for control of methicillin-resistant Staphylococcus aureus (MRSA) in high-risk hospitals areas with a high-level of endemic MRSA. Clin Infect Dis 1998;27:543-550.

32. Struelens MJ, Mertens R. The Groupement pour le Depistage, l'Etude et la Prevention des Infections Hospitalieres. National survey of methicillin-resistant Staphylococcus aureus in Belgian hospitals: detection methods, prevalence trends and infection control measures. Eur J Clin Microbiol Infect Dis 1994:13:56-63.

\title{
Rapid Identification of Staphylococcus aureus
}

\section{Gina Pugliese, RN, MS Martin S. Favero, PhD}

Langlet and coinvestigators from Service de Microbiologie, Centre hospitalier de Versailles, France, have reported a 2-hour method for identification of Staphylococcus aureus based on the detection of the staphylocoagulase, using human prothrombin and a chromogenic substrate. Two hundred forty-two staphylococcal strains (160
$S$ aureus, 82 coagulase-negative staphylococci [CNS]) were collected from four French hospitals. A strain of Staphylococcus intermedius was provided by the Collection of the Pasteur Institute (Paris).

With the substrate SQ149, all $S$ aureus strains gave a positive result: $94.7 \%$ of the methicillin-susceptible $S$ aureus were detected after 1 hour of incubation, but only $52.3 \%$ of the methicillin-resistant $S$ aureus. For methicillin-resistant $S$ aureus, $98.4 \%$ were detected after 2 hours. No falsepositive result was observed for the 82 CNS strains. The chromogenic method showed good within-run and day-to-day precision tests. The sensitivity and the specificity were $99.4 \%$ and $100 \%$, respectively.

FROM: Langlet S, Quentin G, Contant G, Ghnassia JC. A chromogenic method for rapid identification of Staphylococcus aureus. Ann Biol Clin (Paris) 1999;57:191-196. 